\title{
Screening of three promising rice genotypes for rainfed shallow lowlands of red and lateritic ar eas of West Bengal, India
}

\author{
G.K. Mallick* , K. J ana, S. Ghosh and G. Sardar \\ Rice Research Station, Nutanchati, Bankura - 722101 (West Bengal), INDIA \\ *Corresponding author. E-mail - mallickgkgene@gmail.com \\ Received: A pril 10, 2014; Revised received: May 17, 2014; Accepted: J une 1, 2014
}

Abstract: A field experiment was conducted during kharif 2011-12 at Rice Research Station, Bankura, West Bengal to screen promising rice genotypes suitable for rainfed shallow lowland situation of red and lateritic areas of West Bengal. Among the thirty genotypes of rice tested, only three genotypes gave significantly higher yields over best check variety Swarna sub-1 $\left(5324 \mathrm{~kg} \mathrm{ha}^{-1}\right)$. These three promising genotypes of rice were IET $21987\left(6898 \mathrm{~kg} \mathrm{ha}^{-1}\right)$, IET $21979\left(6759 \mathrm{~kg} \mathrm{ha}^{-1}\right)$ and IET $21996\left(6342 \mathrm{~kg} \mathrm{ha}^{-1}\right)$. It is to be noted that IET 21987 is a nomination from Rice Research Station, Bankura, West Bengal. It was nominated to AICRIP trial IVT-RSL during 2010 in the designation of CN 1317-557-56-BNKR 42-2-3.

Keywords: Bankura, IET 21987, Rainfed shallow lowlands, Red and lateritic areas, Rice genotypes

\section{INTRODUCTION}

Rice is a crop which grows under widely divergent agro-ecological situation. It requires specific genotypes for specific regions/seasons. Out of total rice area in Eastern India, 48\% (12.9 mha) is under rainfed lowland, which is dominated by rice during kharif season (Singh and Hossain, 2000). Production of rice in rainfed shallow lowland in Eastern region remained stagnant for a long time. However, for shallow lowlands of Eastern India, a few rice varieties like CR 1002, Pooja, Bipasa were released for cultivation (Ram et al., 2006). This shows that yield improvement per se of varieties bred for these ecosystem, especially for favourable shallow lowlands, is limited. For maximization of yield level in relatively favorable rainfed lowland ecologies in Eastern India thrush should be given to develop new plant type varieties with higher yield and better adaptation. Specific adaptability is the key for varietal success in ecologically handicapped regions. Several breeding lines are being evaluated every year in these ecosystem in trials organized under the All India co-ordinated Rice Improvement Programme (AICRIP).

Previously several early and mid-early rice genotypes have been screened for uplands of red and lateritic areas of West Bengal (Mallick et al., 2012; Mallick et al., 2013a,b,c,d; Mallick and Kundu, 2014). The present study was conducted at Rice Research Station, Bankura, West Bengal as one location of AICRIP trial to screen promising genotypes of rice suitable for cultivation in rainfed shallow lowland situation of Red and Lateritic areas of West Bengal.

\section{MATERIALS AND METHODS}

The experimental material consisted with thirty-three genotypes of rice including three checks. Rice Research Station, Bankura obtained all the genotypes from Directorate of Rice Research, Hyderabad except the local check 'Shashi'. Swarna sub-1, recently started to gain popularity in West Bengal used as regional check. A popular rice variety for rainfed shallow situation in South India, Dhanarasi was used as National Check (Ram et al., 2006). The weather data during crop growing period and composition of rice genotypes tested under this experiment are given in table 1 and 2. Among the rice genotypes tested under this experiment one genotype IET 21987 was nominated from Rice Research Station, Bankura. It was nominated in the designation of CN 1317-557-56BNKR 42-2-3 to Directorate of Rice Research, Hyderabad, for IVT-RSL trial in 2010 and promoted to IVT - RSL 2011.

Seeds were sown in $29^{\text {th }}$ June, 2011 in rice research station's farm, Bankura, West Bengal. Seedlings were transplanted in the main field at the age of thirty days. Spacing between rows and plants were $20 \mathrm{~cm}$ and 15 $\mathrm{cm}$, respectively. Fertilizer dose used $\mathrm{N}, \mathrm{P}_{2} \mathrm{O}_{5}, \mathrm{~K}_{2} \mathrm{O} @$ 60:30:30 kg ha- ${ }^{-1}$. The experiment was laid out in RBD with 3 replications. Records on $50 \%$ flowering, plant height, panicles / sq meter and yield $\left(\mathrm{kg} \mathrm{ha}^{-1}\right)$ were taken. The co-efficient of variation (CV) was estimated according to Burton (1952).

\section{RESULTSAND DISCUSSION}

The performance of thirty genotypes of rice along with national check (Dhanarasi), regional check (Swarna Sub-I) and local check (Shashi) during kharif 2011 at rice research station, Bankura, West Bengal is presented in table $3.50 \%$ flowering ranged from 103 days (IET 22438) to 135 days (IET 22417) and 
Table 1. Meterological data during crop growing period (kharif 2011).

\begin{tabular}{lcccc}
\hline M onth & \multicolumn{2}{c}{ Temperature $\left({ }^{\circ} \mathrm{C}\right)$} & Rainfall $(\mathrm{mm})$ & Rainy days \\
\cline { 2 - 3 } & M aximum & M inimum & & 8 \\
July 2011 & 33.61 & 25.80 & 132.8 & 15 \\
Aug 2011 & 31.94 & 25.31 & 335.8 & 16 \\
September 2011 & 31.82 & 25.10 & 457.4 & 3 \\
October 2011 & 31.61 & 23.91 & 55.2 & 1 \\
November 2011 & 31.15 & 17.41 & 14.0 & \\
\hline
\end{tabular}

Source: Observatory, State Agricultural Farm (SAF), Bankura, West Bengal, India

Table 2. Showing composition of promising rice of genotypes tested under the experiment.

\begin{tabular}{|c|c|c|c|c|}
\hline S. N. & IET No. & Designation & Cross combination & Grain type \\
\hline 1 & IET 21974 & CR 2459-12-8 & Swarna / IR 64 & LB \\
\hline 2 & IET 21987 & CN 1317-557-56-BNKR 42-2-3 & Vikramarya / Mahuri & LB \\
\hline 3 & IET 21996 & CR 2683-15-5-3-1-1 & CRLC 899 / AC 38700 & SB \\
\hline 4 & Swarna Sub-1 & Regional Check & & \\
\hline 5 & IET 22412 & CR 2285-2-3-1-2-1 & Ravana / Mahsuri & MS \\
\hline 6 & IET 22413 & CR 2677-3-1-5-1-1 & Gayatri / Utkala prava & LB \\
\hline 7 & IET 22414 & CR 2986-1-2-1-1-1 & CR 2080-169-2 / Sabita & LS \\
\hline 8 & IET 22415 & CR 2992-1-5-2-1-1 & CR 2006-10 / Hanseswari & MS \\
\hline 9 & IET 22416 & CR 2683-4-1-1-1-1 & CRLC 899 / AC 38700 & LB \\
\hline 10 & IET 22417 & CR 2668-1-4-3-1-1 & Gayatri / AC 38615 & SB \\
\hline 11 & IET 22418 & CR 2676-4-2-1-1-1 & Gayatri / AC 38597 & LB \\
\hline 12 & IET 22419 & CR 2667-5-3-2-1-1 & Gayatri / AC 38599 & SB \\
\hline 13 & Dhanarasi & National Check & & \\
\hline 14 & IET 22420 & CR 2677-3-2-4-1-1 & Gayatri / Utkala prava & SB \\
\hline 15 & IET 22421 & CR 2985-5-2-1-1-1 & Gayatri / Bazaya 65 & SB \\
\hline 16 & IET 22422 & CR 2689-3-2-1-2-1 & Chakaakhi / AC 38707 & LB \\
\hline 17 & IET 22423 & CR 2985-1-5-2-1-1 & Gayatri / Bazaya 65 & MS \\
\hline 18 & IET 22424 & CR 2702-18-56 & Swarna / Ratna & MS \\
\hline 19 & IET 22425 & CR 2702-62-6 & Swarna / Ratna & MS \\
\hline 20 & IET 22426 & CR 997-9-4 & Savitri / CR 658 & SB \\
\hline 21 & Shasi & Local Check & & \\
\hline 22 & IET 22427 & CR-2458-72 & Savitri / Swarna & SB \\
\hline 23 & IET 22428 & CR-2573-621 & Swarna / Gayatri & SB \\
\hline 24 & IET 22429 & CHR 17 & IET 1444 / Basmati 370 & SB \\
\hline 25 & IET 22430 & OR 1878-4 & Swarna / Banskathi & LS \\
\hline 26 & IET 22431 & MGD-1102 & Antarsali / Siddagiri - 1 & SB \\
\hline 27 & IET 22432 & CR 2942-116 & Swarna / Banskathi & LS \\
\hline 28 & IET 22433 & CR 2942-120 & Swarna / Banskathi & LS \\
\hline 29 & IET 22434 & CRR 649-IR 77298-5-6-18 & $\begin{array}{l}\text { IR } 64(\mathrm{WH}) / \text { Aday Sel// 3* IR } \\
64\end{array}$ & LB \\
\hline 30 & IET 22435 & OR 2331-16 & OR 1301-32 / IR 52561 & MS \\
\hline 31 & IET 22436 & OR 2225-37 & OR 1206-26-2 / IR 4221 & LS \\
\hline 32 & IET 22437 & OR 2314-4 & Mahanandi / IR 74 & SB \\
\hline 33 & IET 22438 & MGD-1101 & BPT-5204 / Antarsali & LB \\
\hline
\end{tabular}

average plant height ranged from $88 \mathrm{~cm}$ (IET 22434) to $165 \mathrm{~cm}$ (IET 22418). Highest numbers of panicle / sq meter was observed in IET 21987 (314). Among the three checks, best check was Swarna Sub-I. It gave yield $5324 \mathrm{~kg} \mathrm{ha}^{-1}$. Among the thirty test entries only seven entries namely IET $21987\left(6898 \mathrm{~kg} \mathrm{ha}^{-1}\right)$, IET 21974 (6759 kg ha-1), IET $21996\left(6342 \mathrm{~kg} \mathrm{ha}^{-1}\right)$, IET $22412\left(6064 \mathrm{~kg} \mathrm{ha}^{-1}\right)$, IET $22418\left(5740 \mathrm{~kg} \mathrm{ha}^{-1}\right)$, IET 22423 (5602 kg ha-1) and IET 22426 (5692 kg ha-1) gave more yield than the best check variety Swarna Sub-I, of which only three showed significant difference in respect of yield from the best check variety.
These genotypes were IET 21987 (CN 1317-557-56BNKR 42-2-3), IET 21974 (CR 2459-12-8) and IET 21996 (CR 2683-15-5-3-1-1). This means these three genotypes of rice under this experiment response well to rainfed shallow lowlands in red and lateritic areas of West Bengal. Varieties gaining popularity are invariably from the region of their development suggesting that the specific adaptability is the key to varietal success in ecologically handicapped regions (Siddiq, 2013). Previously Mallik et al. (2006) developed CN 1231-11-7 (IET 17792), a promising rice genotype for the rainfed low land ecosystem in Eastern India. It is 
Table 3. Yield performance of promising rice genotypes at farm of rice research station, Bankura, West Bengal during kharif 2011.

\begin{tabular}{|c|c|c|c|c|c|}
\hline S. N. & IET No. & $\begin{array}{c}\text { Days to } 50 \% \\
\text { flowering }\end{array}$ & $\begin{array}{l}\text { Plant height } \\
(\mathrm{cm})\end{array}$ & Panicles $/ \mathrm{m}^{2}$ & $\begin{array}{c}\text { Y ield } \\
\left(\mathrm{kg} \mathrm{ha}^{-1}\right)\end{array}$ \\
\hline 1 & IET 21974 & 119 & 112 & 310 & $6759 *$ \\
\hline 2 & IET 21987 & 122 & 125 & 314 & $6898 *$ \\
\hline 3 & IET 21996 & 130 & 132 & 305 & $6342 *$ \\
\hline 4 & Swarna Sub-1 & 118 & 105 & 228 & 5324 \\
\hline 5 & IET 22412 & 122 & 142 & 306 & 6064 \\
\hline 6 & IET 22413 & 129 & 134 & 278 & 4166 \\
\hline 7 & IET 22414 & 119 & 160 & 221 & 3472 \\
\hline 8 & IET 22415 & 131 & 164 & 274 & 4907 \\
\hline 9 & IET 22416 & 129 & 135 & 269 & 5138 \\
\hline 10 & IET 22417 & 135 & 140 & 218 & 3981 \\
\hline 11 & IET 22418 & 132 & 165 & 291 & 5740 \\
\hline 12 & IET 22419 & 131 & 140 & 247 & 4351 \\
\hline 13 & Dhanarasi & 119 & 122 & 267 & 5185 \\
\hline 14 & IET 22420 & 129 & 103 & 220 & 4166 \\
\hline 15 & IET 22421 & 126 & 120 & 212 & 4166 \\
\hline 16 & IET 22422 & 127 & 105 & 268 & 5222 \\
\hline 17 & IET 22423 & 119 & 115 & 267 & 5602 \\
\hline 18 & IET 22424 & 119 & 102 & 237 & 4722 \\
\hline 19 & IET 22425 & 115 & 132 & 279 & 5555 \\
\hline 20 & IET 22426 & 119 & 107 & 203 & 3055 \\
\hline 21 & Shasi & 118 & 122 & 230 & 5046 \\
\hline 22 & IET 22427 & 113 & 110 & 225 & 4768 \\
\hline 23 & IET 22428 & 118 & 110 & 280 & 5694 \\
\hline 24 & IET 22429 & 119 & 122 & 222 & 4079 \\
\hline 25 & IET 22430 & 115 & 125 & 238 & 4861 \\
\hline 26 & IET 22431 & 116 & 116 & 187 & 2963 \\
\hline 27 & IET 22432 & 118 & 125 & 178 & 2639 \\
\hline 28 & IET 22433 & 110 & 124 & 216 & 5092 \\
\hline 29 & IET 22434 & 101 & 88 & 186 & 3472 \\
\hline 30 & IET 22435 & 122 & 92 & 248 & 5416 \\
\hline 31 & IET 22436 & 125 & 96 & 229 & 4953 \\
\hline 32 & IET 22437 & 126 & 108 & 241 & 5137 \\
\hline 33 & IET 22438 & 103 & 154 & 273 & 3800 \\
\hline \multicolumn{5}{|c|}{ Experiment Mean } & 4516 \\
\hline \multicolumn{5}{|c|}{ C.D. $(0.05)$} & 702 \\
\hline \multicolumn{5}{|c|}{$\mathrm{CV} \%$} & 9.25 \\
\hline
\end{tabular}

*Significant difference in yield observed over the best check; Note: $-\mathrm{NC}=$ National Check, RC $=$ Regional Check, LC $=$ Local Check

expected that the newly developed rice genotype IET 21987 (CN 1317-557-56-BNKR 42 -2-3) at rice research station, Bankura, West Bengal, India will be an alternative of the popular rice varieties of rainfed low land ecosystem like Dhanrasi, Sabita, Pooja etc. On the basis of this trial it was concluded that IET 21987, IET 21974and IET 21996 were the promising genotypes of rice for Rainfed Shallow lowlands in red and lateritic areas of West Bengal.

\section{ACK NOWLEDGEMENTS}

The authors are grateful to Mr. S. R. Patra, Joint Director of Agriculture (Research), Dr. P. Bhattacharya, Director of Agriculture, Govt. of West Bengal, Jessop buildings, Kol - 1, Dr. B. C. Viraktamath, Project Director of Rice, Dr. N. Shobha Rani, Principal Scientist and Head Crop improvement Division,
Directorate of Rice Research, Rajendranagar, Hyderabad for their valuable guidance and encouragement during the period of investigation. .

\section{REFERENCES}

Burton, W. (1952). Quantitative inheritance in grasses. Proc. $6^{\text {th }}$ Int. G rass Land Congr., I: 277.

Mallick, G.K., Jana, K., Sardar, G. and Biswas, A. (2012). Performance of IET 17509 in Farmer's field of upland situation in West Bengal. Environ. E col., 30:1599-1600.

Mallick, G.K., Jana, K., Sardar, G., Ghosh, S., Mandal, R. and Bhadra, K.K. (2013). Morpho-agronomic characteristics of a newly released rice variety 'Puspa'. Environ. Ecol., 31 (2B): 890-893.

Mallick, G. K. and Kundu, C. (2014). Screening of early rice genotypes for red and lateritic areas of West Bengal. Research in Plant biology, 4 (2): 27-30.

Mallick, G.K., Mandal, R., Ghosh, S., Jana, K., and Mandal, 
R. (2013 b). yield performance of a promising rice culture IET 17509 in red and lateritic areas of West Bengal. International J ournal of Advanced research,1 (9):182-185.

Mallick, G.K., Kundu, C., Ghosh, S. and Sinha, A.K. (2013 c). Evaluation of some international rice genotypes in red and lateritic areas of West Bengal. International J ournal of Current research, 5(11):3360-3363.

Mallick, G.K., Mondal, M., Jana, K., Ghosh, A. and Biswas, A. (2013d): Puspa - A new rice variety alternative to Annada, released for upland areas of West Bengal, India. Eco. Env \& Cons., 19(4):1127 - 1129.

Mallik, S., Santra, C. K., Chatterjee, S. D., Ahmed, J. Barman Roy, S., Sarkarung, S and Atlin, G. (2006). CN 1231-11-7 (IET 17792), a alternative to sabita for the rainfede low land ecosystem in eastern India. IRRN, 312: 34-37.

Ram, T., Mazumder, N.D. and Mishra, B. (2006). Dhanarasi, a new lowland rice variety with Oryza rufipogon genes for improving yield potential and resistance to biotic stresses. IRRN $31.1: 13$.

Singh, V.P. and Hossain, M. (2000). Rice area in different ecosystems in Eastern India. Singh. V.P. and R.K.Singh, editors Rainfed Rice : A source book of best practices and strategies in Eastern India. International Rice Research Institute : 7-8

Siddiq, E. A. (2013). Bridging the rice yield gap in India FAO CORPORATE DOCUMENT REPOSITORY. [Online] Available: http:// www.fao.org./docrep/003/ x6905c/x6905e09.htm 